\title{
Habitat use by two species of Mongolian marmots (Marmota sibirica and M. baibacina) in a zone of sympatry
}

\author{
Konstantin A. ROGOVIN
}

\begin{abstract}
Rogovin K. A.. 1992. Habitat use by two species of Mongolian marmots (Marmota sibirica and M. baibacina) in a zone of sympatry. Acta theriol. 37: $345-350$.

The spatial segregation of Siberian marmots Marmota sibirica Radde, 1862 and grey marmots $M$. baibacina Katschenko, 1899 in the zone of contact in Mongolian Altai $\left(47^{\circ} 30^{\prime} \mathrm{N}, 90^{\circ} 50^{\prime} \mathrm{E}\right)$ and habitat use by Siberian marmots at Aj Bogd Uul mountain $\left(44^{\circ} 43^{\prime} \mathrm{N}, 95^{\circ} 10^{\prime} \mathrm{E}\right)$, where only this species occurs, were studied with the use of discriminant function analysis. In the zone of sympatry the Siberian marmots inhabit productive highland valleys, whereas the grey marmots occupy only tops of ridges reach of alpine vegetation. Three of the four localities where marmots intermediate in coloration and call were observed are characterised by suboptimal conditions (unproductive slopes of ridges). A pronounced niche shift towards the habitat of ridge tops and a slight expansion of niche breadth were found in the allopatric populations of Siberian marmots.
\end{abstract}

Severtzov Institute of Animal Evolutionary Morphology and Ecology, Academy of Sciences of Russia, Leninski pr. 33, 117071 Moscow, Russia

Key words: Marmota, niche shifts, sympatry, Mongolian Altai

\section{Introduction}

The taxonomic status of certain species of Marmota is unclear. Such forms as M. bobak (Muller, 1776), M. baibacina Kastchenko, 1899 and M. sibirica Radde, 1862 have been viewed as subspecies of $M$. bobac (Bannikov 1954, Bobrinsky et al. 1965, Bibikov 1967), or as distinct species (Ognev 1947, Gromov et al. 1965, Sokolov 1977). These different systematic arrangements result in part from the fact that these forms are contiguously allopatric (Vorontzov et al. 1969). Nonetheless, ranges of some allopatric forms are known to have overlapped in the past (Gromov et al. 1965, Kapitonov 1966). Recently, overlap in the ranges of $M$. baibacina and M. sibirica was reported from the territory of Mongolia (Smirin et al. 1985).

Marmota sibirica (Siberian marmot or tarbagan) is widely distributed in eastern and north-eastern Mongolia and inhabits steep lowland valleys, hills and mountain slopes. In the Hangain*, and in the Mongol Altai and Gobi Altai, this species also occupies the alpine belt up to $3800 \mathrm{~m}$ (Bibikov et al. 1987). Marmota

*All geographic names are given according to The Times Atlas of the World, John Bartholomew and Son Ltd., London, 1986. 
baibacina (grey marmot) is a typical mountain form which widely inhabits the Altaic Highland in Russia and penetrates into the Mongolian Altai in its northern part where it inhabits elevations above $3000 \mathrm{~m}$ (Tarasov 1952, Bibikov et al . 1987).

Recently, the distributions of these species along the upper reaches of the Buyant Gol was investigated and a narrow zone of sympatry was found (Smirin et al. 1985). Analyses of coat color and alarm calls revealed the presence of hybrids in the community of Ulagchin Gol valley (the upper reach of Buyant River; Smirin et al. 1985, Formozov and Nikolskiy 1986). Local Mongolian hunters also distinguish three forms of marmots: black marmot (M. baibacina), white marmot (M. sibirica), and an intermediate yellow marmot.

Working in Mongolian and Gobian Altai in June - July of 1983, and 1984 as a member of a Permanent Soviet-Mongolian Biological Expedition, I collected quantitative data on habitat use by these two species. The purpose of this study is to compare habitat use at the zone of contact with habitat use in an area of similar elevation where Siberian marmots exist alone.

\section{Study area and methods}

The spatial segregation of the two marmot species in the zone of contact was studied in Ulagchin Gol valley $\left(47^{\circ} 30^{\prime} \mathrm{N}, 90^{\circ} 50^{\prime} \mathrm{E}\right)$ at about $36 \mathrm{~km}$ to the south from Daluun village (Bayan Ulgyi district; Fig. 1). Four transects of $1 \mathrm{~km}$ length each were established across the slope gradient from alpine river valley to the top of the ridge: valley, lower part of the slope, upper part of the slope, ridge top. I registered active marmots at intervals of $100 \mathrm{~m}$ while walking each transect. Species were identified by call (Smirin et al. 1985) and visually with binoculars. Unidentified individuals were not included in the analysis; specimens with intermediate characters were considered as hybrids between grey and Siberian marmots.

At each point where a marmot was observed (within an area of $20 \mathrm{~m}$ radius from its burrow) three random sample plots of $5 \mathrm{~m}$ radius were estahlished. Five variables were measured in each sample

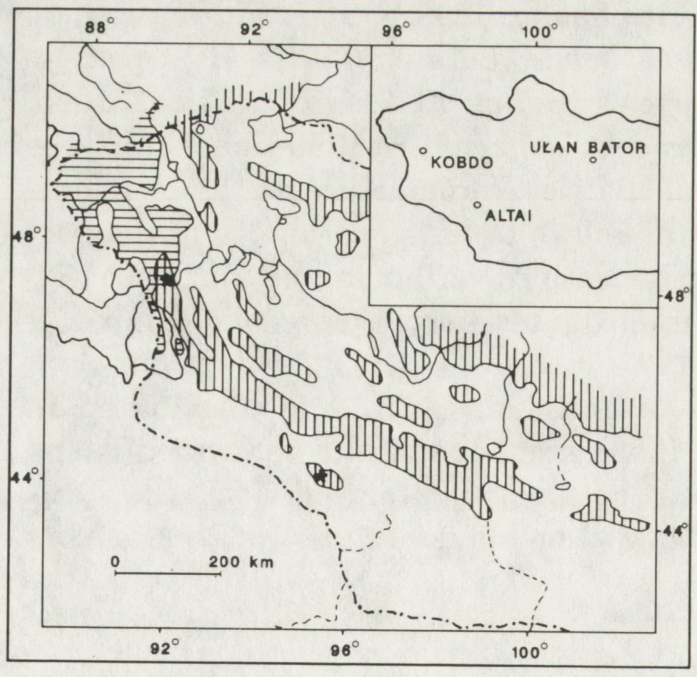

Fig. 1. Ranges of Siberian marmots (vertical lines) and of grey marmots (horizontal lines) in Mongolian Altai and Gobian Altai according to Bibikov et al. (1987) with changes, and localities at which data were collected (asterisks). 
plot (Table 1): number of large stones with diameter $50 \mathrm{~cm}$; mean size of the five biggest stones; percent of the soil surface covered by rock; percent of the soil surface covered by vegetation; angle of the slope. Only means for each observation point were included in further analyses. To obtain data most representative I tried to check transects an equal number of times. The same method were used at Aj Bogd Uul mountain $\left(44^{\circ} 43^{\prime} \mathrm{N}, 95^{\circ} 10^{\prime} \mathrm{E}\right)$ in the Gobi Altai district where an allopatric population of Siberian marmot exist at the upper alpine zone $3000 \mathrm{~m}$ above sea level (Fig. 1).

The data set included 30 observations of Siberian marmots, 30 observations of grey marmots and 4 observations of hybrids at the Ulagchin Gol valley and 25 observations of Siberian marmots at $\mathrm{Aj}$ Bogd Uul mountain-mass. Multivariate discriminant function (canonical) analysis was used for statistical evaluation. Each of the 89 observations were used to compute a separate discriminant score according to the discriminant function equation derived in the analysis. Overall separation of groups was then assessed by averaging discriminant scores for each species. The species mean on each function provided graphable coordinates in two dimensions, one for each function with discriminating ability. Confidence regions for these two dimensional means (centroids) were computed with the principal axes method (Sokal and Rohlf 1969) and plotted. Because discriminant scores are based on linear combinations of standardized coefficients and their distribution therefore approximated a normal distribution, these confidence regions are statistically valid.

Niche overlap was evaluated by comparison of the observation points of species pairs using stepwise discriminant analysis. As a measure of niche overlap I used the overlap in the probability of distributions along the discriminant axes, i. e. the probability of erroneous assignments (Green 1974). Niche breadth was measured as the standard deviation of observation points of a given species from the centroid of this species in the space of discriminant axes (Carnes and Slade 1982).

\section{Results and discussion}

The spatial distribution of two marmot species at Ulagchin-Daba reflects the historical events that have resulted in secondary contact. In the past, the valley of the Buyant river provided a corridor for the Siberian marmots to move from the lowlands to the mountains where they dispersed along the valleys of small tributaries. Grey marmots, which historically occupied mountain tops and alpine plateaus, came into contact with Siberian marmots only at the slopes of watershed ridges at the upper highlands $2500 \mathrm{~m}$ above sea level.

The density of burrows at the ridge top occupied by grey marmots and the density of burrows at the highland valley occupied mostly by Siberian marmots varied from 22 to 37 entrances per ha. The abundance of grey marmots in optimal habitat may be higher. Grey marmots in this region do not dig as much as Siberian marmots. The density of burrows on the slopes is much lower $(10-15$ entrances per ha). At the highland of Aj Bogd Uul Siberian marmots inhabit plateau, mountain tops, saddles between hills, and even large-stone screes. The density of burrows varies from 15 to 45 entrances per ha reaching 32 in the habitat most similar to that used in the Mongolian Altai by grey marmots.

The result of the discriminant analysis objectively confirms the scheme described above and demonstrates the shifts in microhabitat preferences of species. Though three discriminant functions were computed, only the first one made a significant $(p<0.001)$ contribution to separation of groups. The first discriminant 
Table 1. Results of multiple discriminant analysis of niches of marmots from the secondary contact zone between Siberian and grey marmots and from an allopatric population of Siberian marmots. NSD - number of stones $>50 \mathrm{~cm}$ in diameter, MSS - mean size of the five biggest stones, PCR percent of the soil covered by rock, PCV - percent of the soil covered by vegetation, ANS - angle of the slope. DF1 and DF2 are the first two possible discriminant functions, ${ }^{* * *} p<0.001$.

\begin{tabular}{llll}
\hline Information & Variable & DF1 & DF2 \\
\hline Eigenvalue & & 89.57 & 9.96 \\
Chi-square test for significance of discriminant function & & $69.04^{* * *}$ & 9.58 \\
Degrees of freedom & & 15 & 8 \\
Linear correlation between each discriminant function (DF1, & NSD & 0.98 & 0.09 \\
DF2) and habitat variable in the observation vector & MSS & 0.82 & -0.17 \\
& PCR & 0.47 & 0.15 \\
& PCV & 0.36 & 0.70 \\
& ANS & 0.08 & -0.61 \\
\hline
\end{tabular}

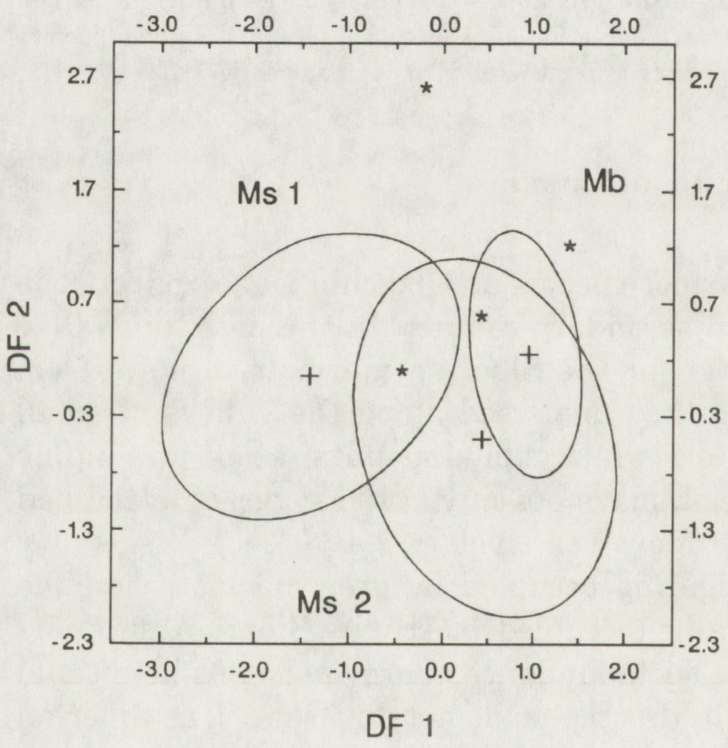

Fig. 2. Ninety percent confidence ellipses for the marmot species observations on first two of discriminant axes (DF1 and DF2): Ms1 - Siberian marmots from the zone of contact in Mongol Altai Nuruu; Ms2 - Siberian marmots from the allopatric population at $\mathrm{Aj}$ Bogd Uul; $\mathrm{Mb}$ grey marmots from the zone of contact in Mongol Altai Nuruu. Crosses indicate niche centers, asterisks indicate position of each intermediate form between Siberian and grey marmots in the zone of their contact.

function accounted for more than $89 \%$ of the variance; the increase of number of large stones per sample plot and of the size of large stones characterized the first discriminant axis. The second function accounted for only $10 \%$ of the variance and could be described as the opposite influence of the slope angle to the percent of vegetation cover (Table 1 ).

Ellipses representing $90 \%$ confidence intervals around the bivariate means on the discriminant axes showed no overlap for the Ulagchin Gol valley (Fig. 2). This indicates a well pronounced segregation of spatial niches of grey and Siberian 
marmots mainly along the first discriminant axis which reflects the altitudinal gradient of conditions along the mountain slope. Niche overlap index between the two species at the contact zone accounts for only $3.0 \%$. There is a significant shift of the bivariate species mean of the Siberian marmot from Aj Bogd Uul towards that of the grey marmot from Ulagchin Gol valley. Niche overlap between the grey marmot from the Mongol Altai Nuruu and the Siberian marmot from Aj Bogd Uul reaches $28 \%$, but only $14 \%$ between two populations of the last species.

Niche breadth indices for each of marmot populations are as follows: grey marmot (Ulagchin Gol) 0.8, Siberian marmot (Ulagchin Gol) 2.4, Siberian marmot (Aj Bog Uul) 2.7.

I am not inclined to explain the slight expansion of niche breadth in the allopatric population of Siberian marmots as niche release because of some latitudinal differences in climate between the Mongol Altai Nuruu and Aj Bogd Uul. Though the climate of highlands in both mountain regions is similar, the low and even the middle slopes of Aj Bogd Uul are extremely arid, being surrounded by very dry desert. The observed niche shift in Siberian marmot populations to some extent may reflect differences in productivity and stability of the vegetation towards the South-East. At the same time it is difficult to explain the absence of Siberian marmots at the tops of mountains and ridges of the Mongolian Altai without enlisting a hypotheses of competition. The competition for home ranges among grey marmots in optimal habitat appears to be high, and can reduce the probability of occupation of ridge tops by Siberian marmots. Three of the four localities where intermediate forms of marmots (hybrids) were observed belong to suboptimal conditions for both of species (slopes of ridges). The features of distribution of Siberian marmots in Aj Bogd Uul and in Mongolian Altai support the hypothesis that a high level of competitiveness of grey marmots can play an important role preventing the expansion of a hybrid zone between populations of two genetically close species. Moreover, the fact that hybrids between the two marmot forms appear rare can be viewed as a good reason to consider them specifically distinct.

Acnowledgements: This work was part of a program for research in biology of Mongolian marmots and was supported by the Permanent Soviet-Mongolian Biological Expedition in 1983. I thank Yu. M. Smirin for his aid on this project in hard climatic conditions of Mongolian highlands. I also thank J. W. Bickman for comments on the original draft of this paper.

\section{References}

Bannikov A. G. 1954. [Mammals of Mongolian People Republic]. Akademija Nauk SSSR, Moskva: 1 - 669. [In Russian]

Bibikov D. I. 1967. [Mountain marmots of Middle Asia and Kazakhstan]. Moskovskoe Obščestvo Ispytatelei Prirody. Materialy k poznaniju fauny i flory SSSR, novaja serija, Otdel. Zool. 44 (59): 1 - 699. [In Russian] 
Bibikov D. I., Pole S. B., Smirin Yu. M. and Myagmarzhav D. 1987. [Distribution and resources of marmots in Mongolian Altai]. Zool. Zh. 66: 1375 - 1388. [In Russian with English summary]

Bobrinskij N. A., Kuznecov B. A. and Kuzjakin A. P. 1965. [Key to Mammals of USSR]. Prosvešcenie, Moskva: 1 - 382. [In Russian]

Carnes B. A. and Slade N. A. 1982. Some comments on niche analysis in canonical space. Ecology 63: $888-893$.

Formozov N. A. and Nikolskiy A. A. 1986. [Alarm calls of grey marmot and tarbagan in the zone of sympatry]. Vestnik Moskovskogo Universiteta 16 (3): 41 - 44. [In Russian with English summary]

Green R. H. 1974. Multivariate niche analysis with temporally varying environmental factors. Ecology 55: $73-83$.

Gromov I. M., Bibikov D. I., Kalabukhov N. I. and Meier M. N. 1965. [Terrestrial sciurids (Marmotinae)]. [In: Fauna SSSR, Mlekopitajušcie]. Nauka, Moskva-Leningrad, 3 (2): 1 - 466. [In Russian]

Kapitonov V. I. 1966. [Distribution of marmots in Central Kazakhstan and perspectives on their trade]. Trudy Inst. Zool. AN KazSSR 26: 94 - 134. [In Russian]

Ognev S. I. 1947. Mammals of USSR and adjacent countries. 5. Rodents: 1 - 809. Izd. Akad. Nauk SSSR, Moskva-Leningrad. [In Russian]. [English translation: Israel Program for Scientific Translations, Jerusalem, 1963].

Smirin Yu. M., Formozov N. A., Bibikov D. I. and Myagmarzhav D. 1985. Characteristics of colonies of two marmot species (Marmota, Rodentia, Sciuridae) in the zone of their contact in Mongolian Altai. Zool. Zh. 64: 1873 - 1885. [In Russian with English summary]

Sokal R. R. and Rohlf F. J. 1969. Biometry. W. H. Freeman and Co., San Francisco: $1-776$.

Sokolov V. E. 1977. [Systematic of mammals]. Vyš̌aja škola, Moskva: 1 - 494. [In Russian]

Tarasov P. P. 1952. New data on distribution of marmots in Southern Siberia and bordering regions of Mongolia. Dokl. Akad. Nauk SSSR 87: 669 - 671. [In Russian with English summary]

Vorontzov N. N., Lyapunova E. A. and Zagoruyko N. G. 1969. Comparative karyology and evolution of isolating mechanisms in genus Marmota. Zool. Zh. 48: 317 - 334. [In Russian with English summary]

Received 29 June 1992, accepted 15 October 1992. 